\title{
RIDGE SUBDUCTION INCORPORATED INTO TECTONIC MODELS OF THE TACONIC OROGENY AND ITS BEARING ON THE ORDOVICIAN UTICA FORELAND BASIN OF NEW YORK STATE
}

\author{
Robert D. Jacobi ${ }^{1,2}$, Charles Mitchell ${ }^{2}$
}

${ }^{1}$ EQT Production; Pittsburgh, PA 2University at Buffalo; Buffalo, NY

Session 267, Paper 267-33, Booth 489, Sept. 27, 2016

T221. Plate Tectonics, Arc-Trench Systems, Cordilleran Tectonics, Sedimentary Basins, Sandstone Provenance, and Geoarchaeology (Posters):

A Celebration of William R. Dickinson's Career

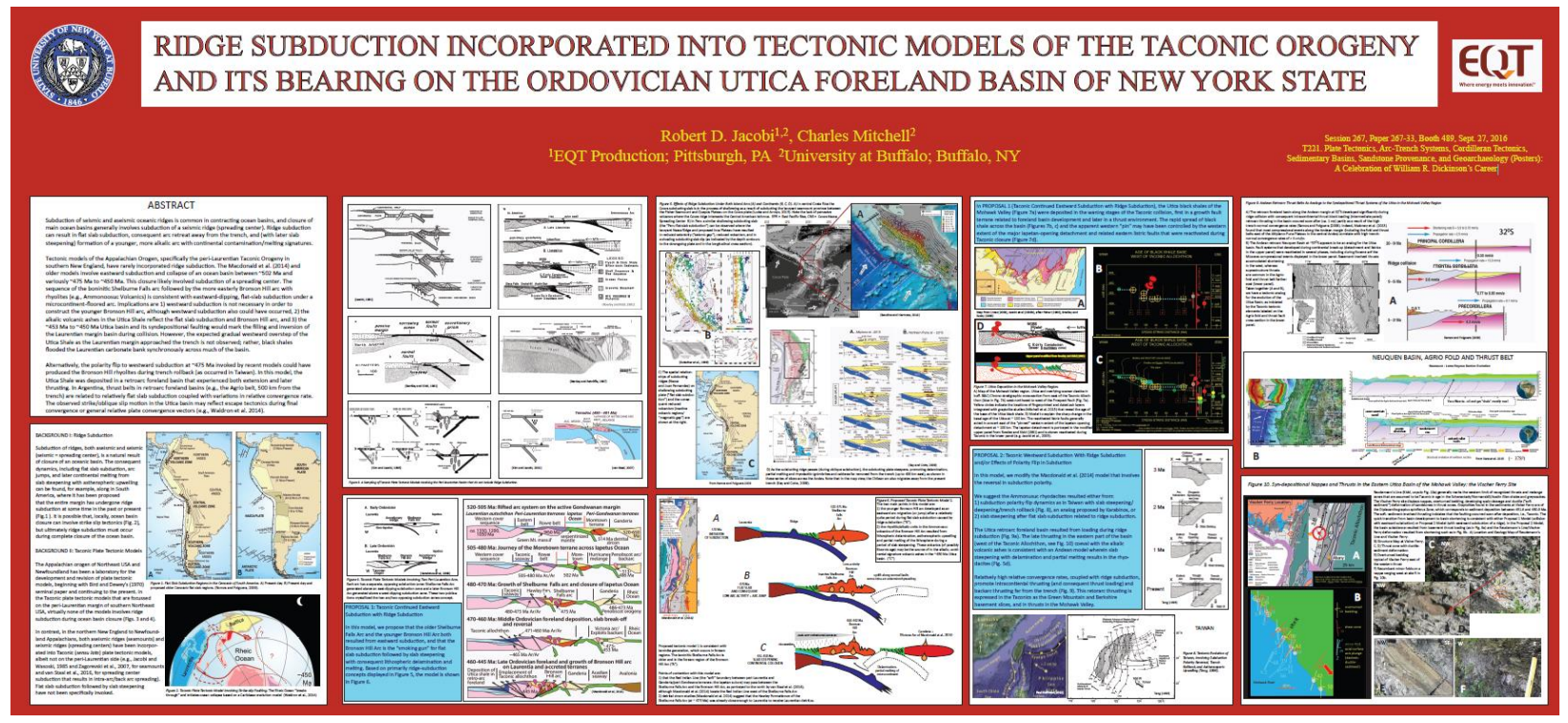

ABSTRACT

Subduction of seismic and aseismic oceanic ridges is common in contracting ocean basins, and closure of main ocean basins generally involve subduction of a seismic ridge (spreading center). Ridge subduction can result in flat slab subduction, consequent arc retreats away from the trench, and (with later slab steepening) formation of a younger, more alkalic arc with continental contamination/melting signatures. Tectonic models of the Appalachian Orogen, specifically the peri-Laurentian Taconic Orogeny in southern New England, have rarely incorporated ridge subduction. The Macdonald et al. (2014) and older models involve eastward subduction and collapse of an ocean basin between $\sim 502 \mathrm{Ma}$ and variously $\sim 475 \mathrm{Ma}$ to $\sim 450 \mathrm{Ma}$. This closure likely involved subduction of a spreading center. The sequence of the boninitic Shelburne Falls arc followed by the more easterly Bronson Hill arc with rhyolites (e.g., Ammonoosuc Volcanics) is consistent with eastward-dipping, flat-slab subduction under a microcontinent-floored arc. Implications are 1) westward subduction is not necessary in order to construct the younger Bronson Hill arc, although westward subduction also could have occurred, 2) the alkalic volcanic ashes in the Utica Shale reflect the flat slab subduction and Bronson Hill arc, and 3) the $\sim 453 \mathrm{Ma}$ to $\sim 450 \mathrm{Ma}$ Utica basin and its syndepositional faulting would mark the filling and inversion of the Laurentian margin basin during collision. However, the expected gradual westward overstep of the Utica Shale as the Laurentian margin approached the trench is not observed; rather, black shales flooded the Laurentian carbonate bank synchronously across much of the basin. 
Alternatively, the polarity flip to westward subduction at $\sim 475 \mathrm{Ma}$ invoked by recent models could have produced the Bronson Hill rhyolites during trench rollback (as occurred in Taiwan). In this model, the Utica Shale was deposited in a retroarc foreland basin that experienced both extension and later thrusting. In Argentina, thrust belts in retroarc foreland basins (e.g., the Agrio belt, $500 \mathrm{~km}$ from the trench) are related to relatively flat slab subduction coupled with variations in relative convergence rate. The observed strike/oblique slip motion in the Utica basin may reflect escape tectonics during final convergence or general relative plate convergence vectors (e.g., Waldron et al. 2014).

\section{BACKGROUND I: Ridge Subduction}

Subduction of ridges, both aseismic and seismic (seismic = spreading center), is a natural result of closure of an oceanic basin. The consequent dynamics, including flat slab subduction, arc jumps, and later continental melting from slab steepening with asthenospheric upwelling can be found, for example, along in South America, where it has been proposed that the entire margin has undergone ridge subduction at some time in the past or present (Fig. 1). It is possible that, locally, ocean basin closure can involve strike slip tectonics (Fig. 2), but ultimately ridge subduction must occur during complete closure of the ocean basin.
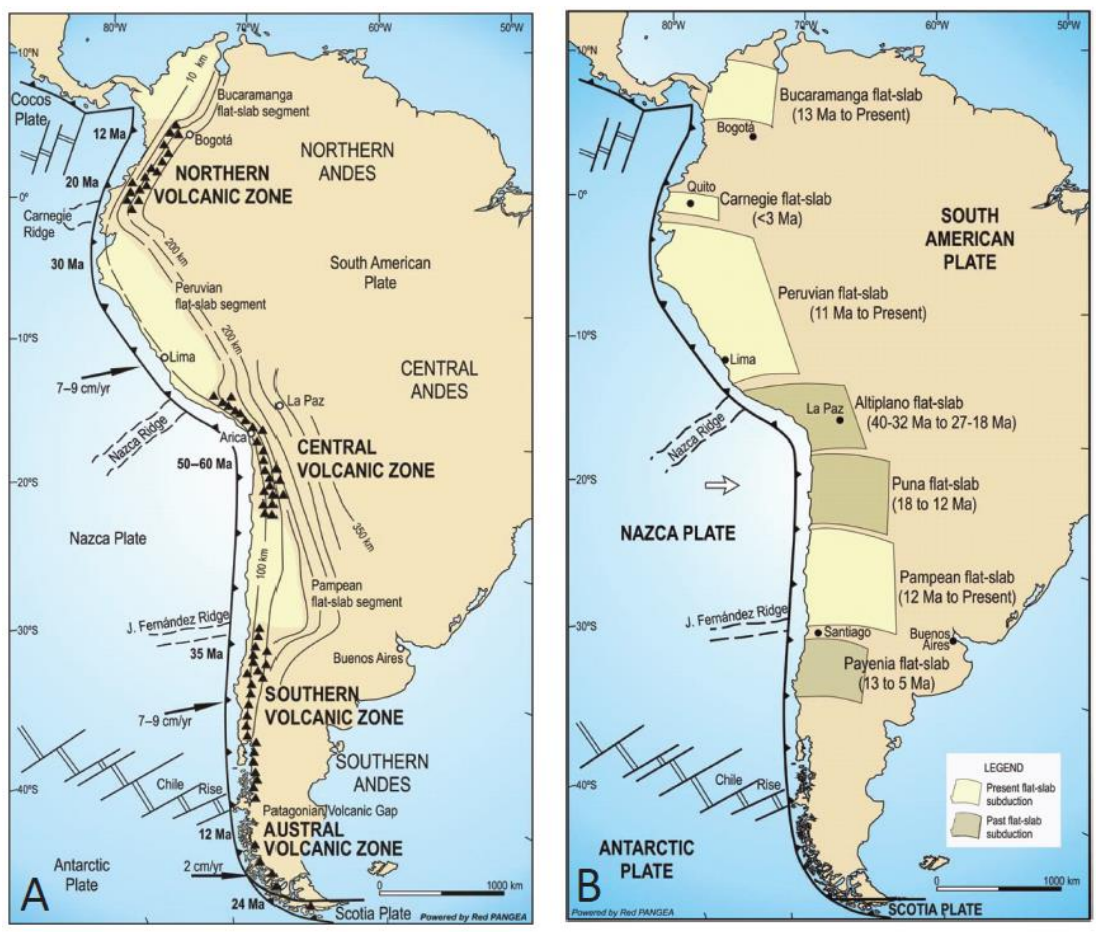

Figure 1. Flat Slab Subduction Regions in the Cenozoic of South America. A) Present day. B) Present day and nronosed older Cenozoic flat slah regions. (Romos and Folguera. 2009).

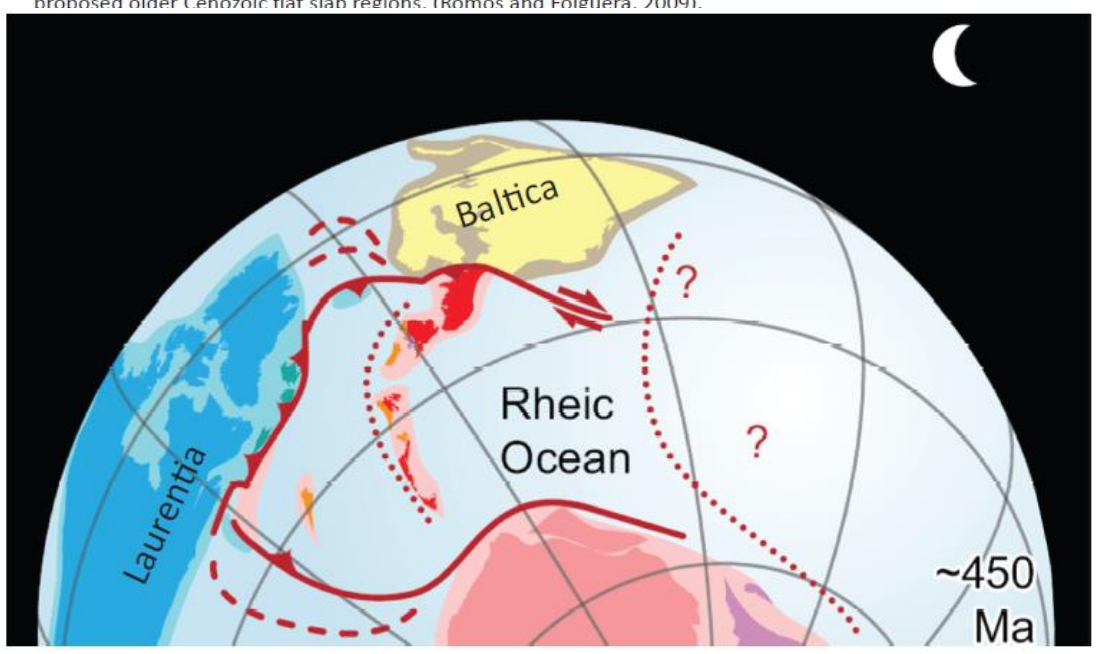

\section{BACKGROUND II:}

Taconic Plate Tectonic Models

The Appalachian orogen of Northeast USA and Newfoundland has been a laboratory for the development and revision of plate tectonic models, beginning with Bird and Dewey's (1970) seminal paper and continuing to the present. In the Taconic plate tectonic models that are focused on the peri-Laurentian margin of southern Northeast USA, virtually none of the models involves ridge subduction during ocean basin closure (Figs. 3 and 4).

In contrast, in the northern New England to Newfoundland Appalachians, both aseismic ridges (seamounts) and seismic ridges (spreading centers) have been incorporated into Taconic (sensu lato) plate tectonic 
models, albeit not on the peri-Laurentian side (e.g., Jacobi and Wasowski, 1985 and Zagorevski et al., 2007, for seamounts and van Staal et al., 2016, for spreading center subduction that results in intraarc/back arc spreading). Flat slab subduction followed by slab steepening have not been specifically invoked.

\section{TACONIC PLATE TECTONIC PROPOSAL 1:}

Taconic Continued Eastward Subduction with Ridge Subduction

In this model, we propose that the older Shelburne Falls Arc and the younger Bronson Hill Arc both resulted from eastward subduction, and that the Bronson Hill Arc is the "smoking gun" for flat slab subduction followed by slab steepening with consequent lithospheric delamination and melting. Based on primarily ridge-subduction concepts displayed in Figure 5, the model is shown in Figure 6.
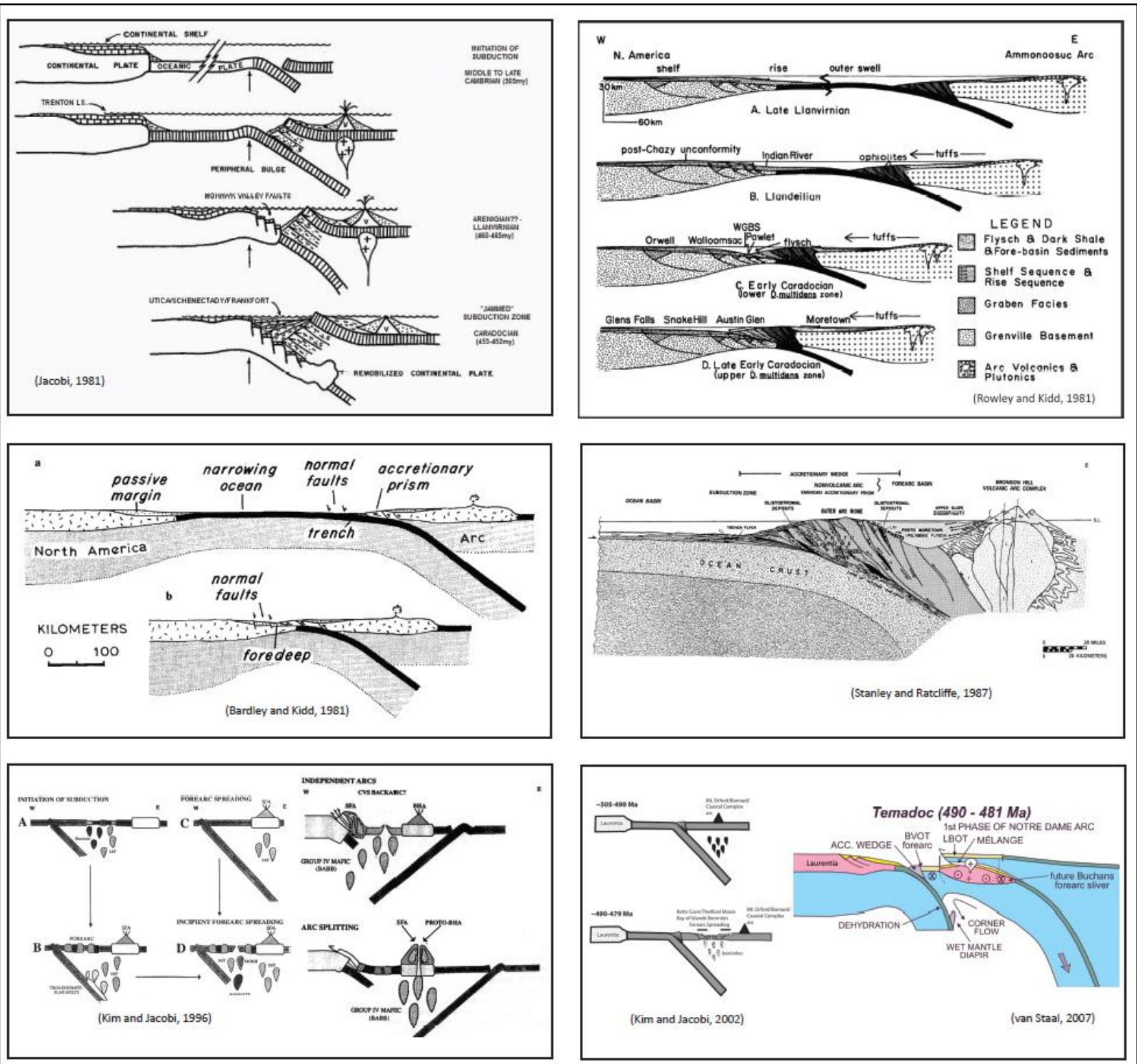

Figure 3. A Sampling of Taconic Plate Tectonic Models Involving the Peri-laurentian Realm that do not Include Ridge Subduction 


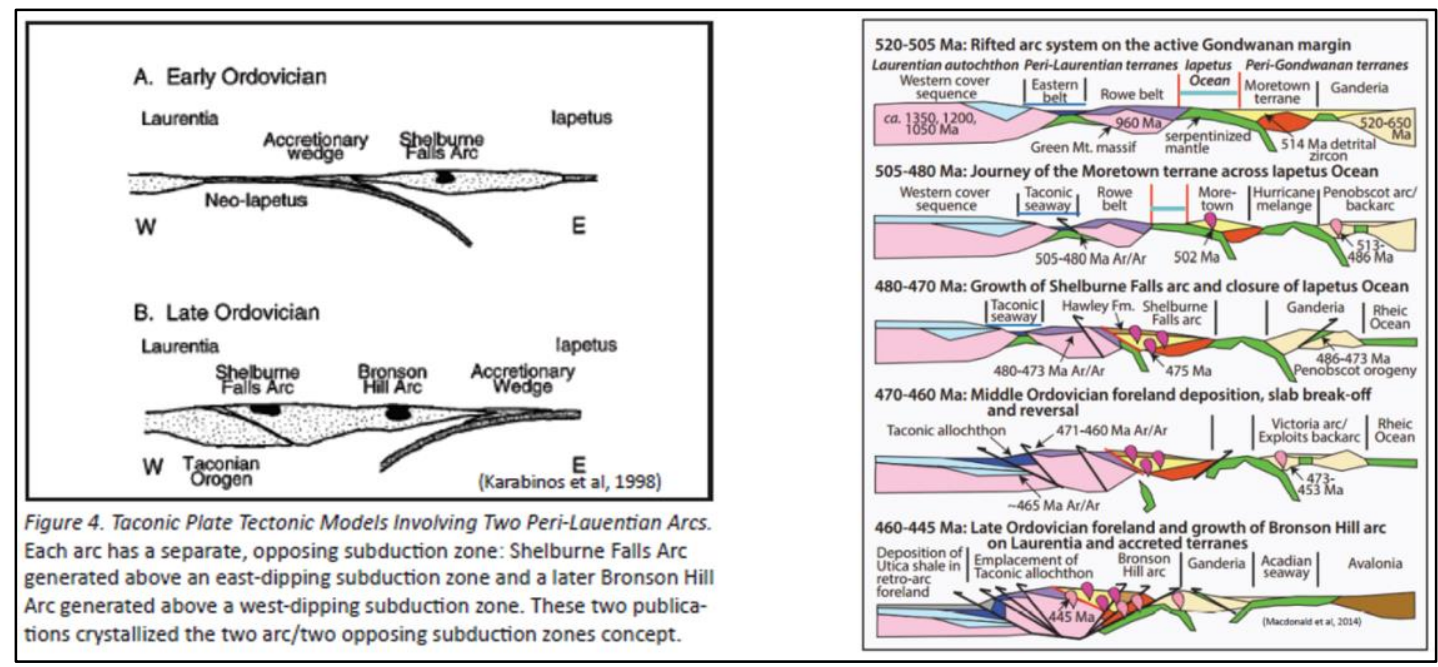

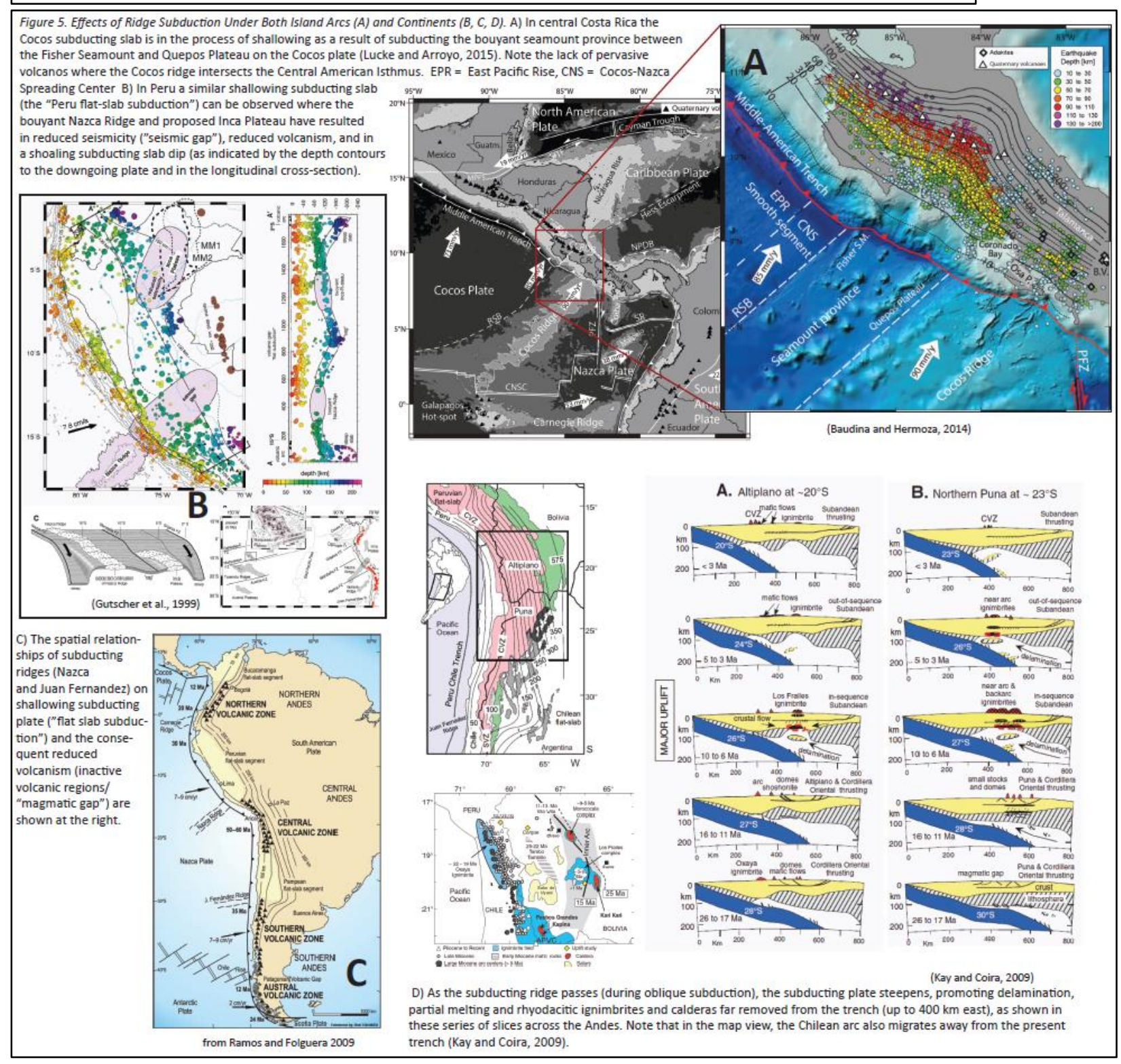




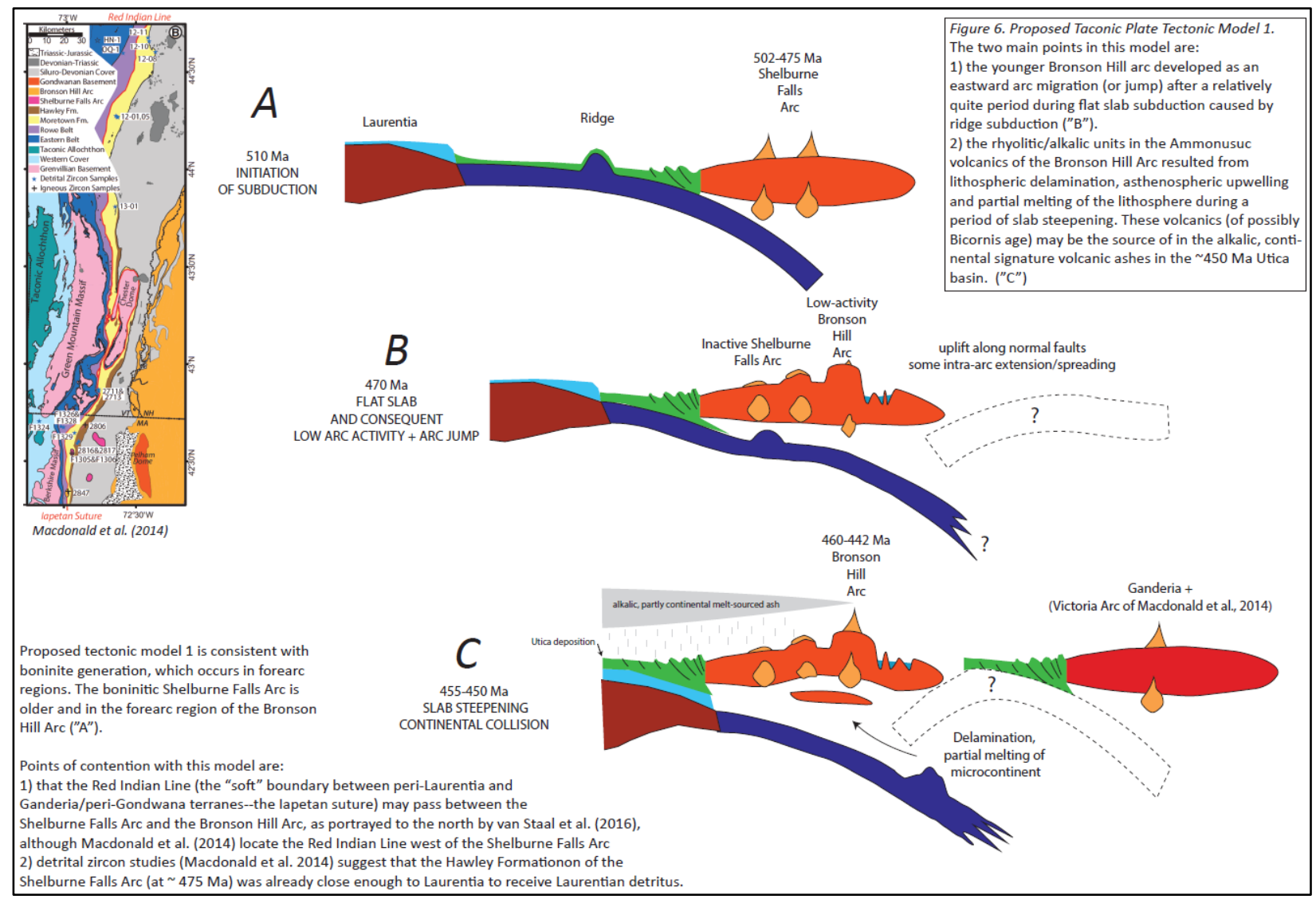

In TACONIC PLATE TECTONIC PROPOSAL 1 (Taconic Continued Eastward Subduction with Ridge Subduction), the Utica black shales of the Mohawk Valley (Figure 7a) were deposited in the waning stages of the Taconic collision, first in a growth fault terrane related to foreland basin development and later in a thrust environment. The rapid spread of black shale across the basin (Figures $7 \mathrm{~b}, \mathrm{c}$ ) and the apparent western "pin" may have been controlled by the western extent of the major lapetan-opening detachment and related eastern listric faults that were reactivated during Taconic closure (Figure 7d).

\section{TACONIC PLATE TECTONIC PROPOSAL 2:}

Taconic Westward Subduction with Ridge Subduction and/or Effects of Polarity Flip in Subduction

In this model, we modify the Macdonald et al. (2014) model that involves the reversal in subduction polarity. We suggest the Ammonoosuc rhyodacites resulted either from:

1) subduction polarity flip dynamics as in Taiwan with slab steepening/ deepening/trench rollback (Fig.

8), an analog proposed by Karabinos, or

2) slab steepening after flat slab subduction related to ridge subduction.

The Utica retroarc foreland basin resulted from loading during ridge subduction (Fig. 9a). The late thrusting in the eastern part of the basin (west of the Taconic Allochthon, see Fig. 10) coeval with the 
alkalic volcanic ashes is consistent with an Andean model wherein slab steepening with delamination and partial melting results in the rhyodacites (Fig. $5 \mathrm{~d}$ ).

Relatively high relative convergence rates, coupled with ridge subduction, promote intracontinental thrusting (and consequent thrust loading) and backarc thrusting far from the trench (Fig. 9). This retroarc thrusting is expressed in the Taconics as the Green Mountain and Berkshire basement slices, and in thrusts in the Mohawk Valley (Figs. 9 and 10).

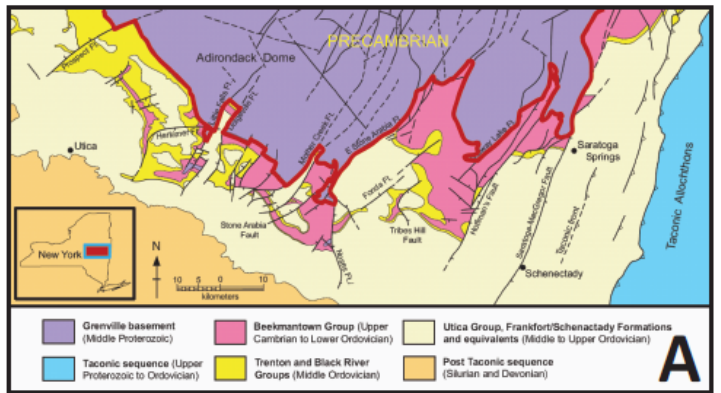

Map from Cross (2008), Jacobi et al (2008b), after Fisher (1980), Bradley and Kusky (1986)

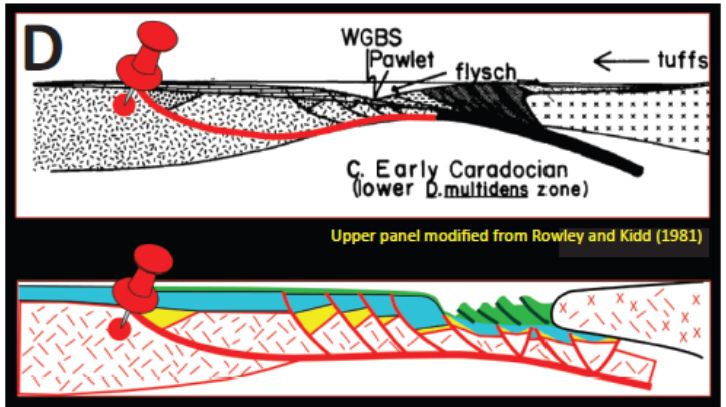

Figure 7. Utica Deposition in the Mohawk Valley Region.

A) Map of the Mohawk Valley region. Utica and overlying coarser clastics in buff. B\&C) Chrono-stratigraphic cross-section from east of the Taconic Allochthon (blue in Fig. 7A) west-northwest to west of the Prospect Fault (Fig. 7a). Yellow circles indicate the locations of fingerprinted and dated ash layers integrated with graptolite studies (Mitchell et al. 2015) that reveal the age of the base of the Utica black shale. D) Model to explain the sharp change in the basal age of the Utica at $\sim 100 \mathrm{~km}$. The reactivated listric faults generally acted in concert east of the "pinned" western extent of the lapetan-opening detachment at $\sim 100 \mathrm{~km}$. The lapetan detachment is portrayed in the modifed upper panel from Rowley and Kidd (1981) and is shown reactivated during Taconic in the lower panel (e.g. Jacobi et al., 2003).

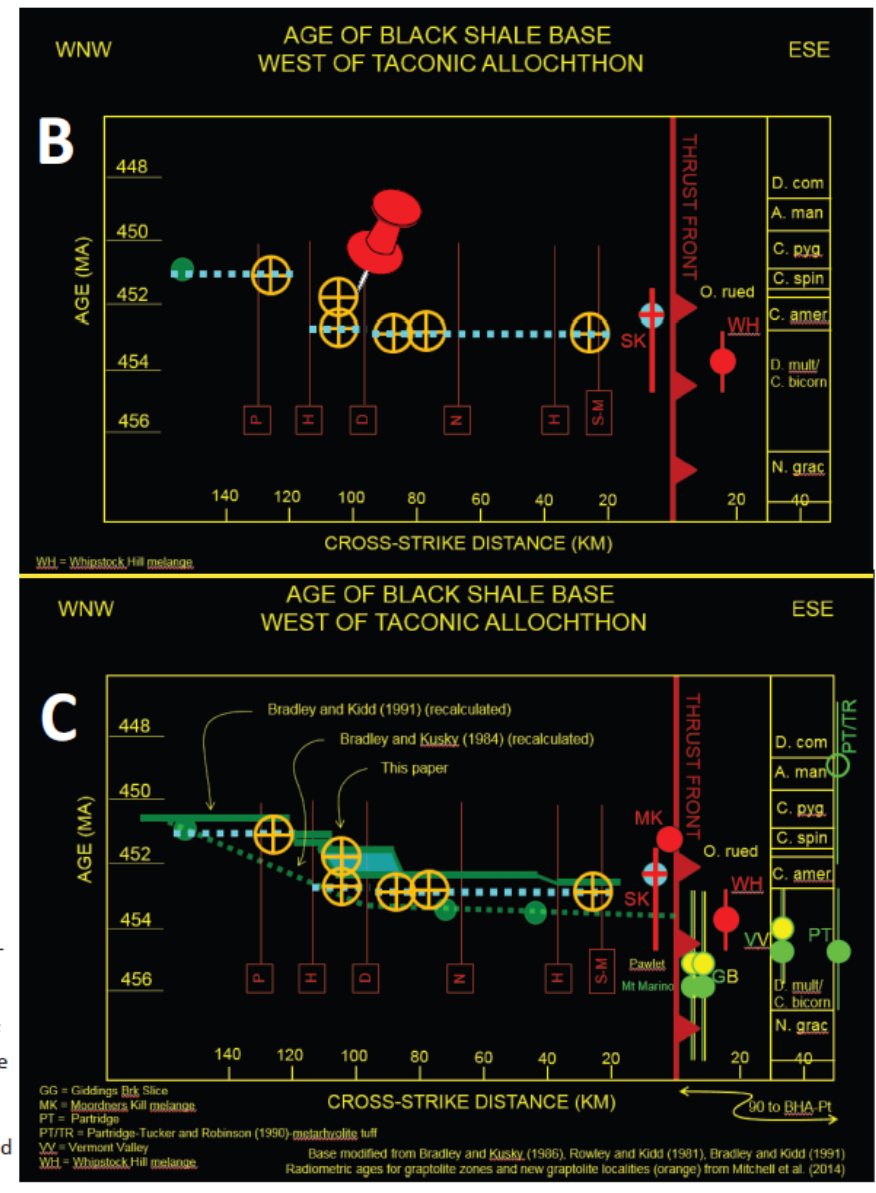




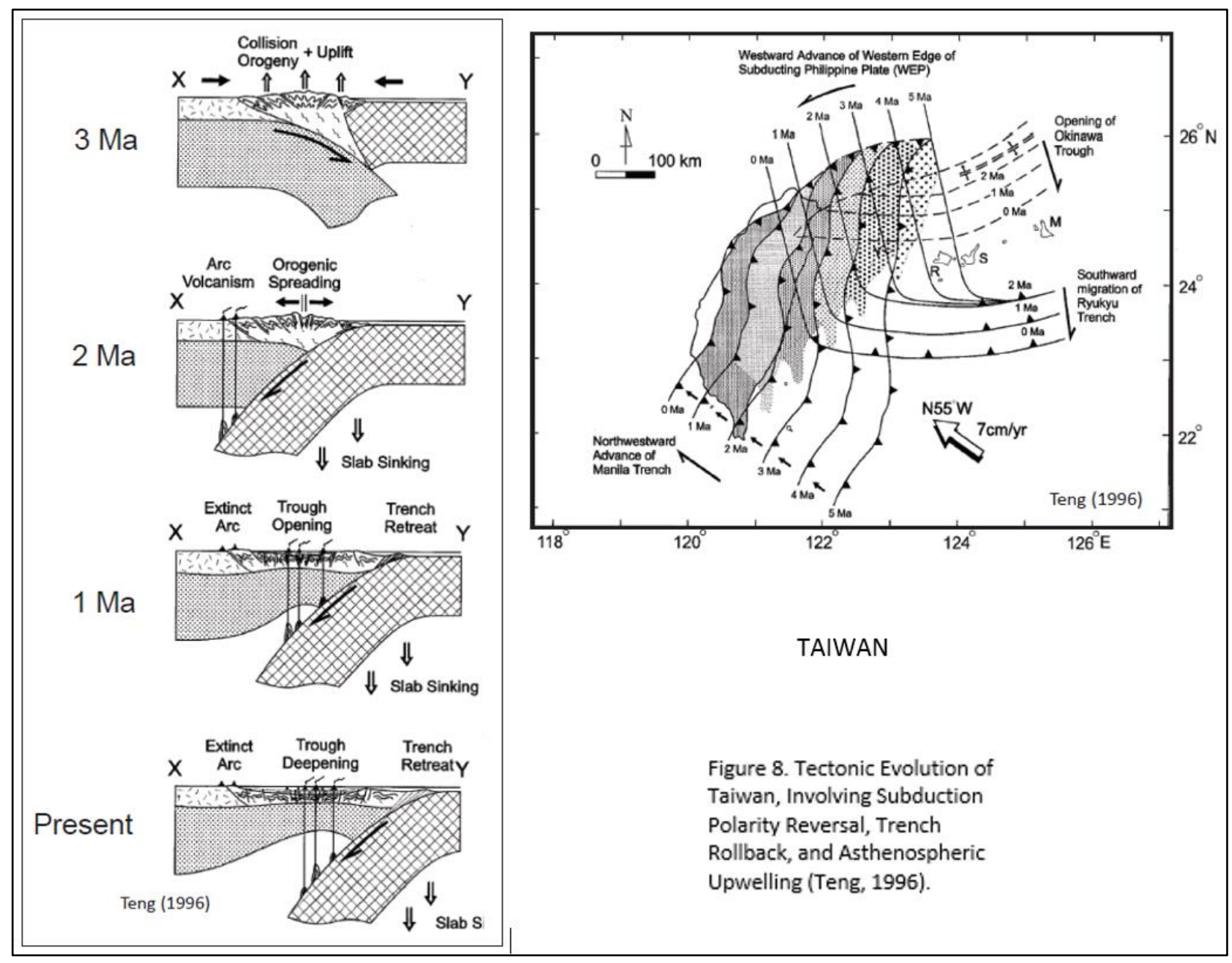




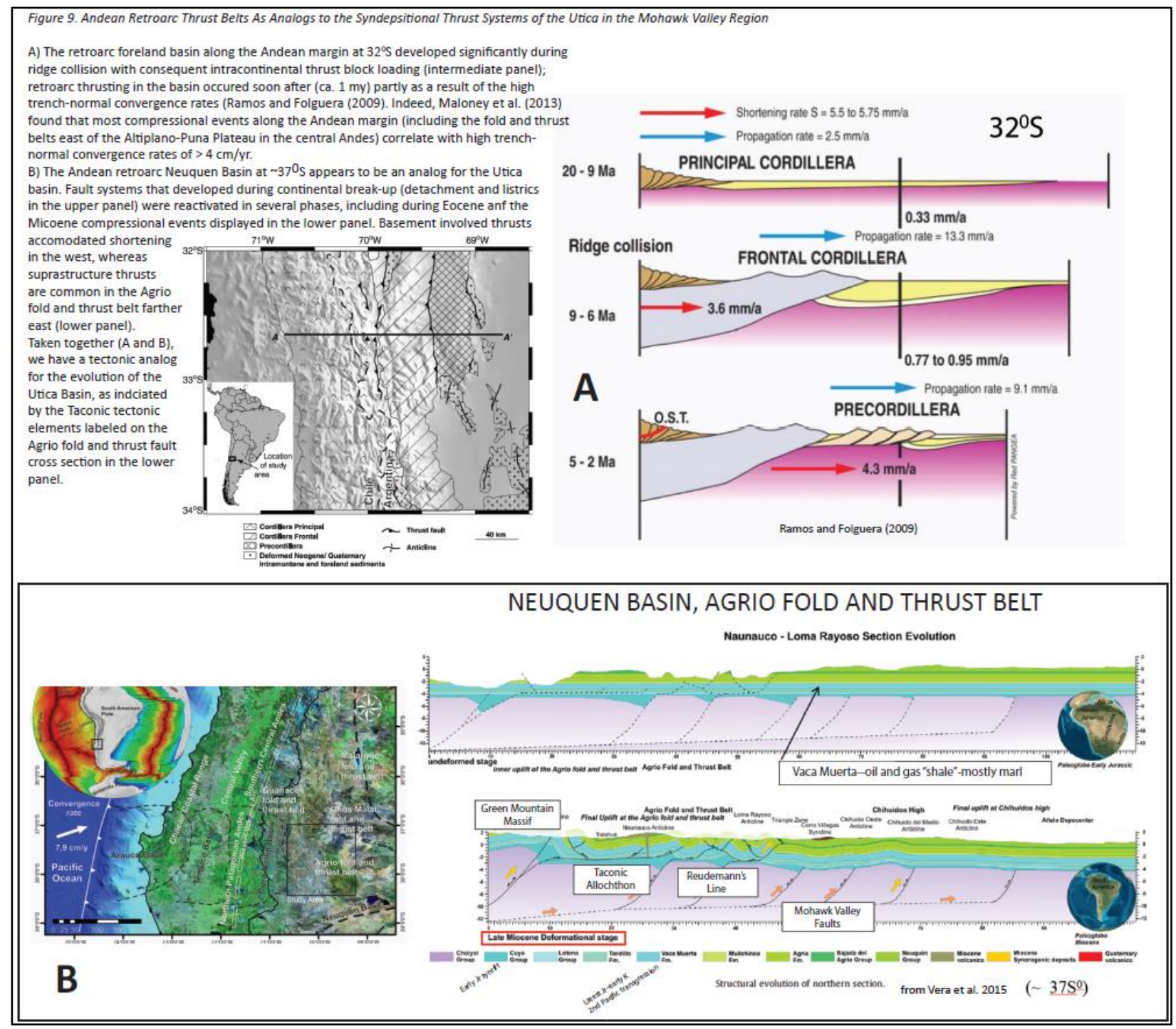




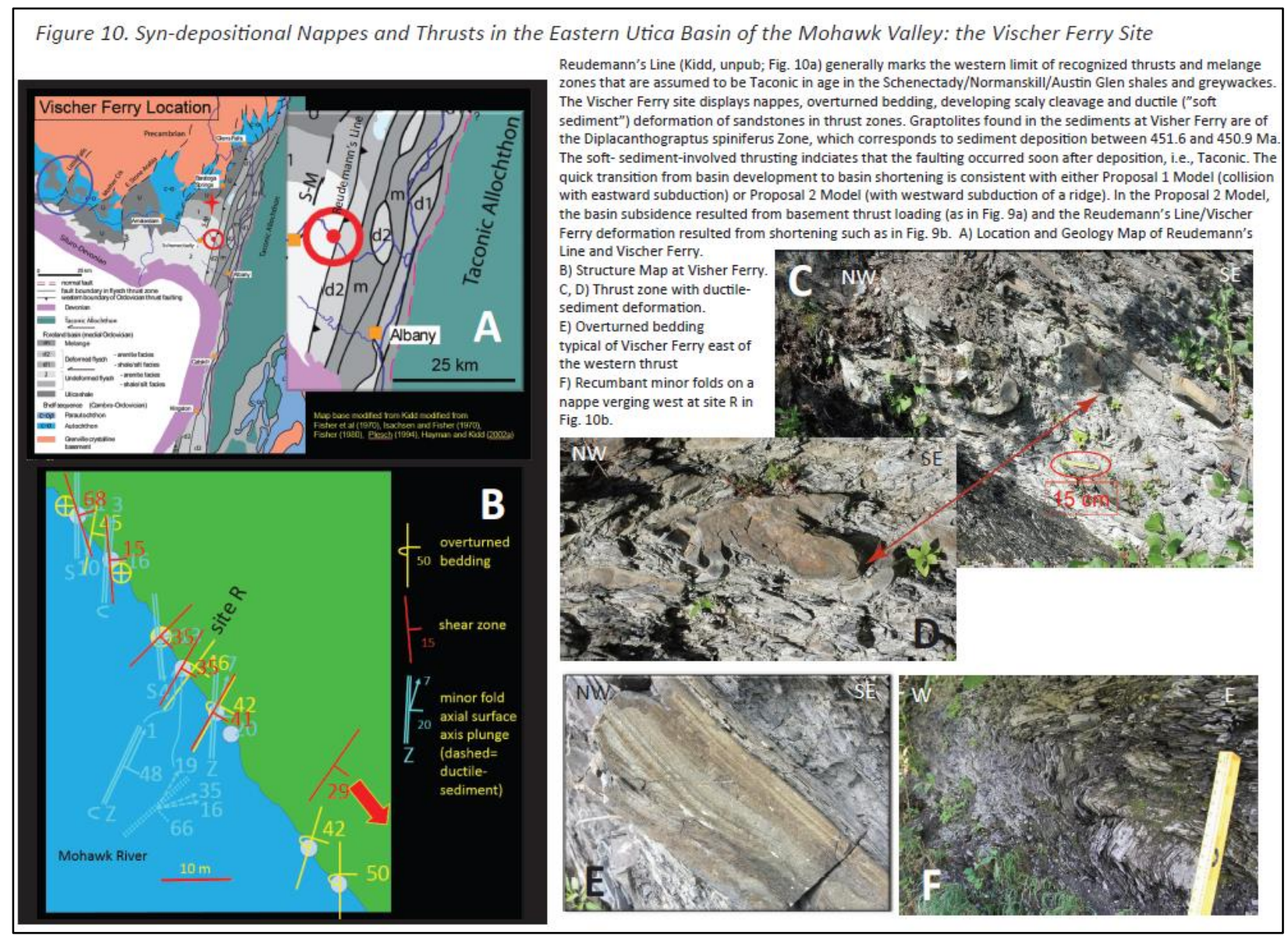

